University of Nebraska - Lincoln

DigitalCommons@University of Nebraska - Lincoln

Agronomy \& Horticulture -- Faculty Publications

Agronomy and Horticulture Department

1998

\title{
Weather and Management Impact on Crop Yield Variability in Rotations
}

Charles Yamoah

Gary E. Varvel

University of Nebraska-Lincoln, gevarvel@windstream.net

Charles Francis

University of Nebraska-Lincoln, cfrancis2@unl.edu

William Waltman

Follow this and additional works at: https://digitalcommons.unl.edu/agronomyfacpub

Part of the Plant Sciences Commons

Yamoah, Charles; Varvel, Gary E.; Francis, Charles; and Waltman, William, "Weather and Management Impact on Crop Yield Variability in Rotations" (1998). Agronomy \& Horticulture -- Faculty Publications. 331.

https://digitalcommons.unl.edu/agronomyfacpub/331

This Article is brought to you for free and open access by the Agronomy and Horticulture Department at DigitalCommons@University of Nebraska - Lincoln. It has been accepted for inclusion in Agronomy \& Horticulture -Faculty Publications by an authorized administrator of DigitalCommons@University of Nebraska - Lincoln. 


\title{
Cropping Systems
}

\section{Weather and Management Impact on Crop Yield Variability in Rotations}

\author{
Charles F. Yamoah, Gary E. Varvel, Charles A. Francis, \\ and William J. Waltman
}

Research Question

\section{Literature Summary}

\section{Study Description}

\section{Applied Questions}

\author{
(ciop

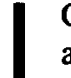
advantages are contingent upon favorable weather and require appropriate management. Unpredictable weather poses risks to dryland crop production. Information on how weather affects yields in different cropping systems and how farmers could respond with management would help minimize risk and stabilize yield and income. We evaluated the effects of preseason and growing season weather variability on continuous and sequential cropping of corn, sorghum, and soybean in a 12-yr span, and suggest how management decisions could influence cropping system performance.

Models of different levels of sophistication have been developed to link yields of individual crops with weather factors. But there is a paucity of information on how weather and management affect yields in whole cropping systems. Furthermore, many models demand a large amount of input data, which is a major limitation to routine application by potential users. This study developed simple empirical models to relate yield and management with a combined index of composite weather variables in whole cropping systems.

The study was conducted from 1984 to 1995 at the Agricultural Research and Development Center near Mead, NE. Correlation and regression analyses were used to relate system performance to weather. Yield was the dependent variable and several combined indices of weather factors were predictor variables. The combined indices of weather or composite weather variables were biological windows (BW) and standardized precipitation index (SPI). Biological windows represent the time during the entire year during which rainfall and air temperature favor biological activities. The biological windows are derived from the mean monthly precipitation and temperature data. The SPI is the difference of precipitation from the long-term average ( $>30 \mathrm{yr}$ ) divided by the standard deviation, a measure used to determine how wet or dry a period of time is compared with average weather patterns, up to a certain date. Both BW and SPI are calculated with simple computer programs. Standard deviation was used as a measure of yield/income variability. Weather effects on yield and income fluctuations of the cropping systems are discussed, along with potentials for the farmer to influence this variability through management.

Which weather factors greatly influence year-to-year variability of crop yields? Are certain crops and cropping systems more resilient to these variable climatic conditions?

Temperature and soil moisture are the two most critical factors for crop yields. Three BW are defined that influence crop growth and development. Biological window 1 is the number of days in the entire year when the soil moisture is dry

Full scientific article from which this summary was written begins on page 219 of this issue. 
and temperature $>41^{\circ} \mathrm{F}$. Biological window 2 is the number of days the soil is moist (between permanent wilting point and field capacity) and temperature > $41^{\circ} \mathrm{F}$, and BW 3 represents number of days that soil is moist with a temperature $>47^{\circ} \mathrm{F}$. These three BW correlated strongly and consistently with yields of corn and soybean but not with grain sorghum yields. Yields decreased as number of dry days increased, while elevated temperature during August also reduced yields. Corn in the 4-yr rotation of oat/clover-sorghum-soybean-corn, and soybean in both 4-yr rotations, were least affected by high August temperature. Corn in the 4-yr rotation of soybean-sorghum-oat/clover-corn and continuous soybean benefitted more than other systems from increased days in BW2. In general, yields of corn and soybean were reduced by drought (BW1) and increased in years with favorable rainfall and temperatures (BW2, BW3). Preseason temperature in April correlated positively with sorghum yield. Also, SPI for the 7 to 9 mo preceding planting influenced yield of the following season's corn crop, especially in the rotational systems. In general, yields of all crops in rotations were consistently higher than in continuous cropping systems, especially at lower $\mathbf{N}$ rates. Risk as measured by income variation generally was higher for corn, similar for soybean, and lower for sorghum in rotations compared to continuous cropping.

Management decisions based on BW include the type of system (continuous vs. rotations) best suited to a given location and the most profitable levels of $\mathbf{N}$ fertilizer based on long-term experience. Specific precipitation index for the months before planting could be used to decide the appropriate $\mathrm{N}$ rate, or more importantly whether to break the rotation cycle and plant corn if the rainfall is highly favorable or grain sorghum if there is low rainfall and below average stored soil moisture. Although these weather variables are useful as management guides, the farmer must also consider relative crop prices, machinery requirements, needs on the farm for specific commodities, and other factors in deciding which crop, systems, and $\mathrm{N}$ rates will be most profitable in a given year, as well as contribute to long-term stability. 


\title{
Cropping Systems
}

\section{Weather and Management Impact on Crop Yield Variability in Rotations}

\author{
Charles F. Yamoah, Gary E. Varvel, Charles A. Francis, ${ }^{*}$ and William J. Waltman
}

\begin{abstract}
Crop rotation offers several advantages to improve farmers' systems worldwide. The positive attributes of rotations are usually dependent upon crop choices, cropping sequence, soil fertility management, and weather factors. Of these, weather is most uncontrollable, but its effects can be partially manipulated through management. This study presents information on how weather affected cropping systems in a 12-yr span. The study also illustrates the use of indices of weather (composite) variables to predict yields. The composite variables are three biological windows (BW) and a standardized precipitation index (SPI). Biological windows based on soil temperature and soil moisture indicate the number of days favorable for or detrimental to crop growth. Biological window 2 (temperature $>41^{\circ} \mathrm{F}+$ moist soil) in combination with May temperature explained more than $80 \%$ of the variability in corn (Zea mays) and soybean (Glycine max) yields. August temperature negatively affected corn and soybean yields, especially in continuous monocrops. Preseason 9-mo SPI (September-May) explained up to $50 \%$ of the subsequent season's corn yields, and this information could influence crop choice. Overall, yields in rotations were higher than in continuous monocropping systems. Nitrogen fertilization increased cereal yields more in continuous monocropping than in rotations with legumes. Corn and soybean appeared more sensitive to soil moisture and temperature variability $(P<0.0001)$ than sorghum (Sorghum bicolor [L] Moench) $(P>0.05)$. Risk as measured by standard deviation in yields or incomes did not differ significantly among systems.
\end{abstract}

$\mathrm{C}$ ROP ROTATION increases productivity by improving soil fertility (Hesterman et al., 1987; Varvel, 1994), controlling weeds (Liebman and Ohno, 1997; Jordan et al., 1995), and reducing insect pest infestation and diseases (Koenning et al., 1995; McSorley et al., 1994; Hendrix et al., 1992). Additionally, growing crops in rotation stabilizes yields (Fribourg and Bartholomew, 1956; Franzleubers et al., 1994; Peterson and Varvel, 1989a,b,c) and income (Crookston, 1984; Peterson et al., 1991; Helmers et al., 1986). Economic gains are possible because crop rotations in general reduce the costs of production.

Success of rotations as a result of the above attributes is a function of weather, crop choices, and management. By its stochastic nature, weather variability introduces risk to pro-

C.F. Yamoah and C.A. Francis, Cent. for Sustainable Agric. Syst., and G.E. Varvel, USDA-ARS, Dep. of Agronomy, Univ. of Nebraska, Lincoln, NE 68583-0949; W.J. Waltman, USDA-NRCS, Lincoln, NE 68508-3866. Joint contribution of Univ. of Nebraska-Lincoln and USDA-ARS-NRCS.Agric. Res. Div. J. Series no. 11822. Received 10 Mar. 1997. *Corresponding author (csas002@unlvm.unl.edu). duction systems. Knowledge of key weather factors and their impacts on major crops and cropping systems may therefore be useful in designing strategies to minimize the effects of adverse weather events. Of utmost importance for the producers' decisionmaking process, however, is knowledge about how much of the current season's potential crop performance can be related to the previous season's climatic records, crop conditions, and soil fertility. Of course, weather after planting is less predictable, but some of the effects could be affected by management decisions.

Several studies relating weather factors to crop yields have been conducted in the USA and Canada (Thompson, 1962; Williams et al., 1975; Dirks and Bolton, 1981; Delcourt and van Kooten, 1995; Peterson et al., 1990). By means of correlations and regression analysis in a 13-yr field study, Dirks and Bolton (1981) attributed 28 to $80 \%$ of the variability in corn yields to monthly precipitation and temperature. Similarly, Asghari and Hanson (1984) developed empirical models to predict corn yields with monthly heat units and precipitation as independent variables. Through multiple regression analysis, Teigen and Thomas (1995) showed that over $90 \%$ of the variability in corn and soybean yields in the USA was explained by fluctuations in monthly precipitation and temperature.

As indicated, the influence of weather changes on yield and yield stability is somewhat system dependent. Crops and varieties behave differently in adverse weather under different input levels and management practices such as fertilization, cropping patterns, and rotations. There are several models available with varying levels of complexity that have the potential to predict crop yields, but only a few models (Stockle et al., 1994) focus on impact of climate and management factors on whole cropping systems. Besides being complex, the large input variable requirements of some of the earlier models limit their routine applicability by potential users. Thus, in the view of Passioura (1973), a model is useful insofar as the input parameters are few and easily obtainable. Our objective for this study was to evaluate the impact of preseason and growing season weather variability on component crops in different cropping systems over $12 \mathrm{yr}$ with corn, sorghum, and soybean at different fertility levels. Specifically, we developed simple empirical relationships with a limited number of individual and composite weather variables to estimate differences in yields and risks associated with crops grown in rotations as compared with monoculture. To relate weather effects on crop yield and variability to management, we discuss the

Abbreviations: BW, biological windows; SPI, standardized precipitation index. 
Table 1. Cropping systems, current crops, and current crop $\mathbf{N}$ rates used in the study, 1984-1995†

\begin{tabular}{lccc}
\hline Cropping system (current crop) & $\begin{array}{c}\text { No N } \\
\text { fertilizer }\end{array}$ & $\begin{array}{c}\text { Medium } \\
\text { N, lb/acre }\end{array}$ & $\begin{array}{c}\text { High N, } \\
\text { lb/acre }\end{array}$ \\
\hline
\end{tabular}

Continuous crops and 2-yr rotations

Continuous com (com)
Continuous soybean (soybean)
Continuous sorghum (sorghum)
Corn-soybean (soybean)
Soybean-corn (com)
Soybean-sorghum (sorghum)
Sorghum-soybean (soybean)

0
0
0
0
0
0
0

$\begin{array}{rr}80 & 160 \\ 30 & 60 \\ 80 & 160 \\ 30 & 60 \\ 80 & 160 \\ 80 & 160 \\ 30 & 60\end{array}$

4yr rotations

O/Clover-sorghum-soybean-(corn) Soybean-sorghum-o/clover-(com) Corn-o/clover-sorghum-(soybean) Sorghum-o/clover-corn-(soybean) Soybean-corn-o/clover-(sorghum) O/Clover-corn-soybean-(sorghum)

$\mathbf{0}$
$\mathbf{0}$
$\mathbf{0}$
$\mathbf{0}$
$\mathbf{0}$
$\mathbf{0}$

$\dagger$ Long-term average $\mathrm{N}$ rates for 2 -yr and 4 -yr rotations were $55 \mathrm{lb} /$ acre (medium rate) and $110 \mathrm{lb} / \mathrm{acre}$ (high rate).

potential producer decisions that could increase or mitigate the possible risk from an unpredictable growing season. These analyses extend the evaluation of crop yields in response to $\mathbf{N}$ rates in rotations previously reported by Peterson and Varvel (1989a,b,c).

\section{MATERIALS AND METHODS}

The experiment was conducted from 1984 to 1995 under rainfed farming conditions at the Agricultural Research and Development Center near Mead, NE, a site typical for the rainfed portion of eastern Nebraska. The site, situated at the western edge of the U.S. Corn Belt, has been subjected to frequent shifts in soil moisture regimes. The soils are classified and mapped as the Sharpsburg clay loam (fine, smectitic, mesic Typic Argiudoll) with $3.1 \%$ organic matter content in the upper 3 in. The experimental design was a split plot with five replications. Main plots were (i) continuous monocropping of corn, sorghum, or soybean; (ii) a 2-yr soybean-corn or soybean-sorghum rotation; (iii) a 4-yr soybean-sorghum-oat (Avena sativa L.)/clover-corn rotation, and (iv) a 4-yr oat/clover-sorghum-soybean-corn rotation. Subplots were $\mathrm{N}$ levels of 0,80 , or $160 \mathrm{lb} / \mathrm{acre}$ for corn and sorghum and $\mathrm{N}$ levels of 0,30 , or $60 \mathrm{lb} / \mathrm{acre}$ for soybean and oat/clover. Main plot size was $29.5 \mathrm{ft}$ by $105 \mathrm{ft}$ and subplot size was $29.5 \mathrm{ft}$ by $32.8 \mathrm{ft}$.

Corn ('Asgrow Rx717', 1984-1987; 'Pioneer 3377', 1988-1991; 'Pioneer 3379', 1992-1995) was planted at 19000 seeds/acre in the first week of May. Grain sorghum ('NK2244', 1984-1987; 'Pioneer 8358', 1988-1995) was planted at 69000 seeds/acre in the last week of May or first week of June. Seeding rate of soybean ('Pella', 1984-1987; 'Pella 86', 1988-1991; 'Dunbar', 1992-1995) was 61000 seeds/acre for sowing between mid-May and early June, depending on conditions each year. Hybrid and variety evaluations were made every 4 yr to assure that those planted were consistent with plantings by local farmers, and to seek the best genetic potential for the area. Hybrid and variety effects were confounded with year. A mixture of sweetclover (Melilotus officinalis L.) and red clover (Trifolium pratense L.) ('Madison' sweet clover [80\%]; 'Common' red
Table 2. Weather variables and indices used in the study and average statistics for 12 yr (1984-1995).

\begin{tabular}{|c|c|c|c|c|c|}
\hline Variable & Symbol & Mean & Standard dev. & Minimum & Maximum \\
\hline Bio window, dry, $>41^{\circ} \mathrm{F}$ & BW1 & 13.6 & 21.0 & 0.0 & 58.0 \\
\hline Bio window, wet, $>41^{\circ} \mathrm{F}$ & BW2 & 165.3 & 62.5 & 75.0 & 227.0 \\
\hline Bio window, wet, $>47^{\circ} \mathrm{F}$ & BW3 & 171.9 & 52.3 & 75.0 & 214.0 \\
\hline April temperature, ${ }^{\circ} \mathrm{F}$ & APT & 50.6 & 2.9 & 46.7 & 54.6 \\
\hline May temperature, ${ }^{\circ} \mathrm{F}$ & MAT & 62.0 & 3.5 & 56.5 & 67.0 \\
\hline June temperature, ${ }^{\circ} \mathrm{F}$ & JUT & 72.3 & 3.0 & 68.3 & 77.1 \\
\hline July temperature, ${ }^{\circ} \mathrm{F}$ & JYT & 75.7 & 2.1 & 71.3 & 78.4 \\
\hline August temperature, ${ }^{\circ} \mathbf{F}$ & AGT & 73.5 & 3.5 & 68.2 & 79.7 \\
\hline April precipitation, in. & APP & 2.9 & 1.7 & 0.52 & 6.2 \\
\hline May precipitation, in. & MAP & 4.4 & 2.3 & 0.56 & 8.0 \\
\hline June precipitation, in. & JUP & 4.0 & 2.2 & 1.62 & 8.7 \\
\hline July precipitation, in. & JYP & 4.9 & 3.9 & 1.16 & 15.8 \\
\hline Aug. precipitation, in. & AGP & 3.8 & 3.5 & 1.01 & 11.9 \\
\hline SPI for Jun-Aug & AGS & 0.18 & 1.24 & -1.52 & 2.88 \\
\hline SPI for Sept-Mar & MRS & 0.17 & 0.91 & -1.04 & 2.52 \\
\hline SPI for Sept-Apr & APS & 0.27 & 1.09 & -1.57 & 2.05 \\
\hline SPI for Sept-May & MAS & 0.18 & 1.18 & -1.98 & 1.51 \\
\hline
\end{tabular}

clover [20\%]) was sown with the oats (Bates, 1984-1987; 'Ogle', 1988-1995) in the 4-yr rotations. The oat/clover was sown usually in the last week of March at a rate of $64 \mathrm{lb} / \mathrm{acre}$ ( $2 \mathrm{bu} / \mathrm{acre}$ ) of oats and $20 \mathrm{lb} /$ acre of clover mix. The clover biomass from the preceding spring oat/clover plots was incorporated into the soil with a tandem disk in mid to late April. Seeding of summer crops was done with a six-row planter and each crop in every rotation was in the field in each of the 12 yr. Weeds in the corn and soybean plots were controlled with a pre-emergence application of either alachlor or metolachlor along with atrazine (corn only), cyanazine (corn only), and linuron (soybean only). Weeds in the sorghum plots were controlled with pre-emergence application of propachlor and cyanazine. All herbicides were used at recommended rates. Crops were harvested in October with a plot combine. A summary of cropping systems investigated is found in Table 1.

Crop yield responses to growing conditions were assessed using regression analysis. The weather variables explored in our regression equations are combined indices of rainfall and soil temperature called $\mathrm{BW}$, cumulative indices of rainfall prior to planting referred to as SPI, and individual monthly growing season temperatures and rainfall amounts. These variables and others used in the analyses are found in Table 2. Biological windows were determined with average monthly precipitation and temperature as input variables in the Newhall Simulation Model (Van Wambeke et al., 1992). The Newhall Simulation Model follows a fixed time-step to distribute monthly rainfall and calculate a moisture condition calendar to approximate days that the soil moisture control section is dry, parts moist and dry, or the entire profile moist. The monthly precipitation is re-apportioned into three parts: a $15-\mathrm{d}$ period of light precipitation, a heavy precipitation event occurring between the 15 th and 16th of the month, and followed by another period of light precipitation. Heavy precipitation events are assumed to represent $50 \%$ of monthly precipitation (Van Wambeke, 1987). For each of three events the precipitation is added to the soil profile, the soil moisture condition or status is calculated for the number of days during which each condition (dry, moist/dry, and moist) prevailed in the soil moisture control section (from about 10 in. to 40 in.). The Newhall Simulation Model calculates soil moisture across a soil moisture control section, which approximates an effec- 
tive rooting depth in the soil profile. The Newhall Simulation Model is adapted to flexible soil moisture storage, so the rooting zone available water-holding capacity can be varied for specific soils. Soil temperatures are calculated at $\mathbf{2 0}$ in. and derived from monthly air temperatures. Soil temperature thresholds are set for cumulative days less than $41^{\circ} \mathrm{F}$, days where soil temperature is $>41^{\circ} \mathrm{F}$, but less than $47^{\circ} \mathrm{F}$, and days above $47^{\circ} \mathrm{F}$. By definition, BW1 represents the cumulative number of days in the entire year when the soil moisture level was below permanent wilting point (dry) and the soil temperature was greater than $41^{\circ} \mathrm{F}$; BW2 represents the cumulative number of days when the soil moisture level in the root zone was between field capacity and permanent wilting point (moist) and temperature was greater than $41^{\circ} \mathrm{F}$; and $\mathrm{BW} 3$ represents the cumulative number of days when the soil moisture level in some of the root zone was between field capacity and permanent wilting point (moist) and temperature was greater than $47^{\circ} \mathrm{F}$. Biological windows represent moisture and soil temperatures that are unfavorable (BW1) or favorable (BW2, BW3) for soil biological activities, root growth, and soil mineralization (Waltman et al., 1997).

The SPI for any period is the difference between precipitation received and the long-term mean $(>30 \mathrm{yr}$ ) divided by the standard deviation. Four important intervals are identified: AGS is the June-August SPI for the current growing season; MRS is the September-March, or preseason index up to planting oat/clover; APS is the September-April, or preseason index up to planting corn; MAS is the September-May SPI, or preseason up to planting soybean and sorghum. A SPI value for a given period $>0$ indicates above average soil moisture, and $<0$ signifies below average soil moisture; an SPI of -2 or less is indicative of extreme drought (McKee et al., 1992). A statistical summary of these variables is shown in Table 2 .

Correlations and multiple regressions were run with crop yields as dependent variables and weather factors as predictor variables. Correlations among the predictor variables were examined to check for multicollinearity (i.e., significant correlations among predictor variables). As expected, variables based on the same weather data were significantly correlated (results not shown). Yield standard deviations were multiplied by the average prices of corn $(\$ 2.24 / \mathrm{bu})$, sorghum $(\$ 1.97 / \mathrm{bu})$, and soybean $(\$ 5.94 / \mathrm{bu})$ to provide an indication of income variability or risk associated with each system (Helmers et al., 1986). Differences among standard deviations were evaluated using the Hartley test $(0.05$ probability level; Nester and Wasserman, 1974). A functional form of elasticity $\left(E_{c}\right)$ was calculated as a measure of relative sensitivity of crop yield (dependent variable) to significant weather factors. The formula is $E_{c}=(d y / d x)^{*}(X / Y)$ where $d y / d x$ is the regression coefficient for the significant weather factors, and $X$ and $Y$ are the respective means of the weather variable and crop yield. In practical terms, $E_{c}$ is the percentage change in yield due to $1 \mathrm{~d}$ change in a $\mathrm{BW}$, or $1^{\circ} \mathrm{F}$, or 1 in. of precipitation.

A minimum of $4: 1$ ratio of observations per predictor variable was suggested for studies of this nature by Tabachnick and Fidell (1983). Draper and Smith (1966) recommend at least 10 observations for each predictor variable. This study used 12 complete sets of yield and climatic
Table 3a. Yield and risk assessment of corn in cropping systems in eastern Nebraska, 1984-1995.

\begin{tabular}{|c|c|c|c|c|c|c|}
\hline \multirow[b]{2}{*}{ System† } & \multicolumn{2}{|c|}{$0 \mathrm{~N}$} & \multicolumn{2}{|c|}{$80 \mathrm{lb}$ N/acre } & \multicolumn{2}{|c|}{$160 \mathrm{lb} N /$ acre } \\
\hline & $\begin{array}{l}\text { Yield, } \\
\text { bu/acre }\end{array}$ & $\begin{array}{l}\text { Risk, } \\
\text { \$/acre* }\end{array}$ & $\begin{array}{c}\text { Yield, } \\
\text { bu/acre }\end{array}$ & $\begin{array}{l}\text { Risk, } \\
\text { \$/acre }\end{array}$ & $\begin{array}{l}\text { Yield, } \\
\text { bu/acre }\end{array}$ & $\begin{array}{l}\text { Risk, } \\
\text { \$/acte }\end{array}$ \\
\hline $\mathrm{CC}$ & 63 & 43 & 108 & 73 & 125 & 82 \\
\hline S-C & 102 & 56 & 132 & 92 & 131 & 83 \\
\hline O/Cl-G-S-C & 121 & 69 & 143 & 86 & 137 & 68 \\
\hline S-G-O/Cl-C & 114 & 105 & 124 & 100 & 135 & 100 \\
\hline
\end{tabular}

* Risk=yield standard deviation $\times \$ 2.24$ (corn price/bu); Hartley test at 0.05 probability level is 2.4 and nonsignificant.

† CC=continuous corn; $\mathrm{S}-\mathrm{C}=$ soybean-corn; $\mathrm{O} / \mathrm{Cl}-\mathrm{G}-\mathrm{S}-\mathrm{C}=$ clover-sorghum-soybeancorn; S-G-O/Cl-C = soybean-sorghum-clover-corn. LSD (0.05) for yield =15.9 bu/acre.

Table 3b.Yield and risk assessment of sorghum in cropping systems in eastern Nebraska, 1984-1995.

\begin{tabular}{|c|c|c|c|c|c|c|}
\hline \multirow[b]{2}{*}{ System† } & \multicolumn{2}{|c|}{$0 \mathrm{~N}$} & \multicolumn{2}{|c|}{$80 \mathrm{lbN} / \mathrm{acre}$} & \multicolumn{2}{|c|}{$160 \mathrm{lbN} / \mathrm{acre}$} \\
\hline & $\begin{array}{l}\text { Yield, } \\
\text { bu/acre }\end{array}$ & $\begin{array}{l}\text { Risk, } \\
\text { \$/acre* }\end{array}$ & $\begin{array}{l}\text { Yield, } \\
\text { bu/acre }\end{array}$ & $\begin{array}{l}\text { Risk, } \\
\text { \$/acre }\end{array}$ & $\begin{array}{l}\text { Yield, } \\
\text { bu/acre }\end{array}$ & $\begin{array}{l}\text { Risk, } \\
\text { \$/acre }\end{array}$ \\
\hline CG & 50 & 49 & 95 & 68 & 104 & 62 \\
\hline S-G & 89 & 50 & 102 & 54 & 105 & 44 \\
\hline $\mathrm{S}-\mathrm{C}-\mathrm{O} / \mathrm{Cl}-\mathrm{G}$ & 90 & 58 & 101 & 58 & 101 & 61 \\
\hline O/Cl-C-S-G & 90 & 52 & 104 & 52 & 106 & 51 \\
\hline
\end{tabular}

* Risk=yield standard deviation $\times \$ 1.97$ (sorghum price/bu); Hartley test at 0.05 probability level is 1.5 and nonsignificant.

$+\mathbf{C G}=$ continuous sorghum; $\mathbf{S}-\mathbf{G}=$ soybean-sorghum; $\mathrm{S}-\mathrm{C}-\mathrm{O} / \mathrm{Cl}-\mathrm{G}=$ clover-cornsoybean-sorghum; O/Cl-C-S-G = soybean-corn-clover-sorghum. LSD $(0.05)$ for yield $=11.3 \mathrm{bu} /$ acre

Table 3c. Yield and risk assessment of soybean in cropping systems in eastern Nebraska, 1984-1995.

\begin{tabular}{|c|c|c|c|c|c|c|}
\hline \multirow[b]{2}{*}{ System $†$} & \multicolumn{2}{|c|}{$0 \mathrm{~N}$} & \multicolumn{2}{|c|}{$30 \mathrm{lbN} / \mathrm{acre}$} & \multicolumn{2}{|c|}{$60 \mathrm{lbN} / \mathrm{acre}$} \\
\hline & $\begin{array}{l}\text { Yield, } \\
\text { bu/acre }\end{array}$ & $\begin{array}{l}\text { Risk, } \\
\text { \$/acre* }\end{array}$ & $\begin{array}{l}\text { Yield, } \\
\text { bu/acre }\end{array}$ & $\begin{array}{l}\text { Risk, } \\
\text { \$/acre }\end{array}$ & $\begin{array}{c}\text { Yield, } \\
\text { bu/acre }\end{array}$ & $\begin{array}{l}\text { Risk, } \\
\text { \$/acre }\end{array}$ \\
\hline CS & 36 & 60 & 35 & 59 & 35 & 56 \\
\hline C-S & 39 & 62 & 34 & 64 & 37 & 61 \\
\hline G-S & 38 & 55 & 38 & 54 & 40 & 59 \\
\hline C-O/Cl-G-S & 40 & 56 & 40 & 65 & 42 & 60 \\
\hline G-O/Cl-C-S & 40 & 68 & 38 & 63 & 39 & 68 \\
\hline
\end{tabular}

* Risk=yield standard deviation $\times \$ 5.94$ (soybean price/bu) Hartley test at 0.05 probability level is 1.3 and nonsignificant.

† CS = continuous soybean; C-S = corn-soybean; $\mathrm{G}-\mathrm{S}=$ sorghum-soybean; $\mathrm{C}-\mathrm{O} / \mathrm{Cl}$ G-S = corn-clover-sorghum-soybean; G-O/Cl-C-S = sorghum-corn-clover-soybean LSD $(0.05)$ for yield $=1.4$ bu/acre.

observations in 12 yr. Given the high expense and logistical challenges involved in conducting long-term and multi-site experiments, the creation of composite variables becomes a useful strategy in the development of prediction equations with fewer, but important, explanatory variables.

\section{RESULTS AND DISCUSSION}

\section{Yield and Income Variability}

Ideal cropping systems combine high yield with minimum variability or risk. The problem with variability is that below average yields represent a measure of potential loss in income; consequently, major farm management decisions are based on reducing variability. Risk may be reduced if some cropping systems have smaller fluctuations in yield and income than other systems. Producers may view risk differently based on their resource endowments.

Twelve-year average yields are shown for corn (Table $3 a$ ), sorghum (Table $3 b$ ), and soybean (Table $3 c$ ) at three $N$ 
Table 4. Correlation of selected weather variables with crop yields in Eastern Nebraska.

\begin{tabular}{|c|c|c|c|c|c|c|c|}
\hline $\begin{array}{l}\text { Previous } \\
\text { crop } \neq\end{array}$ & $\begin{array}{l}\text { Current } \\
\text { crop }\end{array}$ & $\begin{array}{l}\mathrm{N} \text { fert., } \\
\mathrm{lb} / \text { acre } \\
\text { (kg/ha) }\end{array}$ & BW1 & BW2 & BW3 & AGT & AGP \\
\hline Com & Com & 0 & $-0.57^{*}$ & $0.68 * *$ & $0.66^{* *}$ & $-0.82^{* *}$ & NS \\
\hline Corn & Com & 80 & $-0.68 * *$ & $0.72 * *$ & $0.70^{* *}$ & $-0.94 * *$ & NS \\
\hline Corn & Com & 160 & $-0.63^{*}$ & $0.78 * *$ & $0.66^{* *}$ & $-0.92 * *$ & NS \\
\hline Soybean & Com & 0 & $-0.55 \dagger$ & $0.77^{* *}$ & $0.64^{*}$ & $-0.76^{* *}$ & NS \\
\hline Soybean & Com & 80 & $-0.65^{*}$ & $0.86^{* *}$ & $0.75^{* *}$ & $-0.76 * *$ & NS \\
\hline Soybean & Com & 160 & $-0.79 * *$ & $0.94^{* *}$ & $0.84^{* *}$ & $-0.89^{* *}$ & NS \\
\hline O/Cl-G-S & Com & 0 & NS & $0.66^{*}$ & $0.53 \dagger$ & $-0.67^{*}$ & NS \\
\hline O/Cl-G-S & Com & 80 & $-0.67^{* *}$ & $0.85^{* *}$ & $0.75^{* *}$ & $-0.84^{* *}$ & NS \\
\hline O/Cl-G-S & Com & 160 & $-0.51 \dagger$ & $0.81 * *$ & $0.60^{*}$ & $-0.77^{* *}$ & NS \\
\hline S-G-O/Cl & Com & 0 & $-0.68 * *$ & $0.88^{* *}$ & $0.75^{* *}$ & $-0.87^{* *}$ & NS \\
\hline S-G-O/Cl & Com & 80 & $-0.77 * *$ & $0.92^{* *}$ & $0.85^{* *}$ & $-0.86^{* *}$ & NS \\
\hline S-G-O/Cl & Com & 160 & $-0.64^{*}$ & $0.88^{* *}$ & $0.75^{* *}$ & $-0.84 * *$ & NS \\
\hline Soybean & Soybean & 0 & $-0.70 * *$ & 0.91 ** & $0.75^{* *}$ & $-0.71^{* *}$ & $0.60^{*}$ \\
\hline Soybean & Soybean & 30 & $-0.72^{* *}$ & $0.92^{* *}$ & $0.77^{* *}$ & $-0.73^{* *}$ & $0.53 \dagger$ \\
\hline Soybean & Soybean & 60 & $-0.72 * *$ & $0.87^{* *}$ & $0.76^{* *}$ & $-0.67^{* *}$ & $0.56^{*}$ \\
\hline Com & Soybean & 0 & $-0.74^{*}$ & $0.83^{* *}$ & $0.82 * *$ & $-0.61 *$ & $0.51 \dagger$ \\
\hline Corn & Soybean & 30 & $-0.77^{*} *$ & $0.86 * *$ & $0.81^{* *}$ & $-0.65^{*}$ & NS \\
\hline Corn & Soybean & 60 & $-0.76 * *$ & $0.81^{* *}$ & $0.82 * *$ & $-0.61 *$ & NS \\
\hline Sorghum & Soybean & 0 & $-0.70^{* *}$ & $0.84^{* *}$ & $0.78^{* *}$ & $-0.65^{*}$ & $0.57^{\star}$ \\
\hline Sorghum & Soybean & 30 & $-0.57^{*}$ & $0.77^{* *}$ & $0.68 * *$ & $-0.50 \dagger$ & NS \\
\hline Sorghum & Soybean & 60 & $-0.64^{*}$ & $0.76^{* *}$ & $0.72^{* *}$ & NS & $0.53 \dagger$ \\
\hline $\mathrm{C}-\mathrm{O} / \mathrm{Cl}-\mathrm{G}$ & Soybean & 0 & $-0.63^{*}$ & $0.80^{* *}$ & $0.72 * *$ & $-0.61^{*}$ & $0.50^{\circ}$ \\
\hline $\mathrm{C}-\mathrm{O} / \mathrm{Cl}-\mathrm{G}$ & Soybean & 30 & $-0.51 \dagger$ & $0.72 * *$ & $0.60^{*}$ & NS & NS \\
\hline $\mathrm{C}-\mathrm{O} / \mathrm{Cl}-\mathrm{G}$ & Soybean & 60 & NS & $0.61^{*}$ & $0.53 \dagger$ & NS & NS \\
\hline G-O/Cl-C & Soybean & 0 & $-0.63^{*}$ & $0.80^{* *}$ & $0.71^{* *}$ & NS & $0.61^{*}$ \\
\hline G-O/Cl-C & Soybean & 30 & $-0.61 *$ & $0.77^{* *}$ & $0.70^{* *}$ & NS & $0.54 \dagger$ \\
\hline G-O/Cl-C & Soybean & 60 & $-0.69 * *$ & $0.72 * *$ & $0.72 * *$ & NS & $0.68 * *$ \\
\hline Sorghum & Sorghum & 0 & NS & NS & NS & NS & NS \\
\hline Sorghum & Sorghum & 80 & NS & NS & NS & NS & NS \\
\hline Sorghum & Sorghum & 160 & NS & NS & NS & NS & NS \\
\hline Soybean & Sorghum & 0 & NS & NS & NS & $-0.58^{*}$ & NS \\
\hline Soybean & Sorghum & 80 & NS & NS & NS & $-0.61^{*}$ & NS \\
\hline Soybean & Sorghum & 160 & NS & NS & NS & NS & NS \\
\hline $\mathrm{S}-\mathrm{C}-\mathrm{O} / \mathrm{Cl}$ & Sorghum & 0 & NS & $0.55 \dagger$ & $0.63^{*}$ & $-0.67 * *$ & NS \\
\hline $\mathrm{S}-\mathrm{C}-\mathrm{O} / \mathrm{Cl}$ & Sorghum & 80 & NS & NS & NS & NS & NS \\
\hline $\mathrm{S}-\mathrm{C}-\mathrm{O} / \mathrm{Cl}$ & Sorghum & 160 & NS & NS & NS & NS & NS \\
\hline $\mathrm{O} / \mathrm{Cl}-\mathrm{C}-\mathrm{S}$ & Sorghum & 0 & NS & NS & NS & $-0.52 \dagger$ & NS \\
\hline O/Cl-C-S & Sorghum & 80 & NS & NS & NS & -0.36 & NS \\
\hline O/Cl-C-S & Sorghum & 160 & NS & NS & NS & $-0.52 \dagger$ & NS \\
\hline
\end{tabular}

$\dagger, * *$ denote significance at $0.10,0.05$ and 0.01 probability levels respectively. $\ddagger \mathrm{C}=$ corn, $\mathrm{S}=$ soybean, $\mathrm{G}=$ sorghum, $\mathrm{O} / \mathrm{Cl}=$ oat + clover.

levels. Yield standard deviations are multiplied by average crop prices to provide a measure of income variation, or economic risk. Com in either a 2- or 4-yr rotation produced higher yields than continuously grown corn with 0 and $80 \mathrm{lb}$ N/acre (Table 3a), and only with $160 \mathrm{lb}$ N/acre did continuous corn approach yields of corn in rotation. Corn in a 4-yr rotation (oat/clover-sorghum-soybean-corn) with $80 \mathrm{lb}$ $\mathrm{N} /$ acre yielded $143 \mathrm{bu} / \mathrm{acre}$, the highest in the trial. It is apparent from the results that a high ( $160 \mathrm{lb} \mathrm{N} / \mathrm{acre})$ fertilizer rate is essential in continuous corn to obtain yields equal to corn in rotation at a modest rate of $\mathrm{N}$ application. In spite of a wide variation in risk as measured by crop income (standard deviation $\times$ crop price), risk values did not differ significantly, and thus gross incomes were equally stable according to the Hartley test (Nester and Wasserman, 1974). Nitrogen fertilization resulted in significantly higher yields for each increment of $\mathrm{N}$ added in continuous com but only for the first $80 \mathrm{lb} \mathrm{N} /$ acre in two of the rotations. Growing corn continuously without $\mathbf{N}$ fertilizer recorded significantly lower yield ( $63 \mathrm{bu} / \mathrm{acre}$ ), with half the variation in income compared with the high $\mathbf{N}$ rate, similar to results of Dirks and Bolton (1981). Such a low-yielding system will not be attractive to farmers in nonsubsistence agricultural settings where land prices are high and profit maximization is the primary consideration. For environmental and economic reasons, com in the four year O/Cl-G-S-C or the two-year S$\mathrm{C}$ with $80 \mathrm{~N} \mathrm{lb}$ /acre is preferred to the O/Cl-G-S-C and S-C with 160 lb $\mathrm{N}$ because it uses $50 \%$ less $\mathrm{N}$ for the same yield. In contrast, com in the $\mathrm{S}-\mathrm{G}-\mathrm{O} / \mathrm{Cl}-\mathrm{C}$ system had increased yield in response to each increment of added $\mathrm{N}$ fertilizer. Based on these results farmers would no doubt choose rotations over com continuous cropping, and would apply moderate levels of $\mathrm{N}$ fertilizer to cut production costs and minimize potential for $\mathbf{N}$ loss from the system.

Sorghum in rotations produced higher yields than in continuous systems with no added $\mathrm{N}$ fertilizer, but there were no significant differences at the medium and high $N$ rates (Table 3b). Sorghum preceded by soybean in a 2-yr or 4-yr rotation responded to the first increment with higher yield, but not to additional $\mathbf{N}$ fertilizer. In contrast to continuous sorghum, there was no apparent yield response by sorghum in rotation to the second increment of added $\mathbf{N}$ fertilizer. Yield of continuous sorghum without $\mathrm{N}$ was $50 \mathrm{bu} / \mathrm{acre}$ and was significantly less than yields in all the rotations. Across all systems and $\mathrm{N}$ levels, there were no significant differerences in yield variability and risk. Based on these results, farmers would be likely to apply a moderate rate of $\mathrm{N}$ to sorghum in rotations, and might apply a higher rate to continuous sorghum in order to maximize profits.

Soybean yields were significantly higher in rotations in three of four comparisons within the 0 and medium $\mathbf{N ~ l e v - ~}$ els, and in four comparisons at the high $\mathrm{N}$ level, compared with continuous soybean. There was no significant difference among standard deviations or income risk among the treatments. What is noteworthy is the small range from the lowest ( $34 \mathrm{bu} / \mathrm{acre}$ ) to highest ( $42 \mathrm{bu} / \mathrm{acre}$ ) yields in soybean (about 20\%); in contrast the range from the lowest to highest cereal yields was over $100 \%$. Soybean is definitely a more stable yielding crop across a wide range of year to year changes in weather and management.

\section{Correlation analyses}

Correlations were explored as an initial step to identify relationships between weather variables and yield as well as among the explanatory variables used in the subsequent regression analysis (data not shown). For com, BW (BW1, BW2, BW3) and August temperature (AGT) indicated strong and significant linear association with yields in all the rotational. sequences and fertilizer levels (Table 4). The other variables were not significantly related to corn yields. Negative correlation coefficients of com yields with BW1 and AGT show the negative effects of moisture shortage through the season and high August temperature, respectively. Conversely, corn yields improved in direct proportion to the cumulative number of days in the year when the soil root zone was moist and temperature was above $41^{\circ} \mathrm{F}$, positive conditions for com growth and development as well as soil biological activity.

Sorghum was less sensitive to the same weather variables that influenced corn yields (Table 4). April temperature (APT, data not shown) was positively correlated with sorghum yields in several systems, probably due to a favorable soil environment for seed germination and early crop establishment. The resilience of sorghum to weather fluctu- 
Table 5. Correlations (r-values) of preseason standardized precipitation indices (SPIs) with current season corn yield.

\begin{tabular}{lccc}
\hline System $\ddagger$ & $\begin{array}{c}\text { Sept-March } \\
\text { SPI (MRS) }\end{array}$ & $\begin{array}{c}\text { Sept.- April SPI } \\
\text { (APS) }\end{array}$ & $\begin{array}{c}\text { Sept.- May SPI } \\
\text { (MAS) }\end{array}$ \\
\hline CC-0 & 0.40 & 0.43 & $0.61 \dagger$ \\
CC-80 & 0.35 & 0.42 & 0.40 \\
CC-160 & 0.31 & 0.35 & 0.24 \\
S-C-0 & $0.66^{*}$ & 0.50 & 0.53 \\
S-C-80 & $0.65^{*}$ & $0.61^{*}$ & $0.71^{*}$ \\
S-C-160 & $0.56 \dagger$ & $0.58 \dagger$ & $0.60 \dagger$ \\
O/Cl-G-S-C-0 & $0.61^{*}$ & $0.70^{* *}$ & $0.73^{* *}$ \\
O/Cl-G-S-C-80 & 0.44 & $0.61^{*}$ & 0.45 \\
O/Cl-G-S-C-160 & $0.66^{*}$ & $0.52 \dagger$ & 0.43 \\
S-G-O/Cl-C-0 & $0.52 \dagger$ & $0.53 \dagger$ & 0.41 \\
S-G-O/Cl-C-80 & $0.51 \dagger$ & $0.53 \dagger$ & $0.54 \dagger$ \\
S.G-O/Cl-C-160 & $0.61^{*}$ & 0.48 & 0.42 \\
\hline
\end{tabular}

$\dagger, * * *$ denote significance at $0.10,0.05$, and 0.01 probability levels respectively. $\mp \mathrm{C}=$ Corn, $\mathrm{S}=$ soybean, $\mathrm{G}=$ sorghum, $\mathrm{O} / \mathrm{Cl}=$ oat $/$ clover.

ations and adverse weather, in particular below average precipatation or reduced soil moisture is widely reported (Doggett, 1970; Wall and Ross, 1970). Continuous sorghum is less affected by elevated August temperature (two significant out of six comparisons) than sorghum in rotations (four significant out of six comparisons).

Correlations of soybean yields to weather variables were similar to those of corn, in that they were affected by August temperature and precipitation. Soybean yields were correlated positively with days of good growing conditions (BW2, BW3) and negatively with days with dry soil (BW1). Soybeans were less affected by August temperature when following sorghum; our results provide no explanation for this.

A set of composite variables representing preseason 7-, 8-, and 9-month SPI beginning September 1 correlated positively and significantly with the following season's yield in the majority of the rotational systems (Table 5). Yields of continuous corn were unaffected by the preseason SPI. These preseason SPI variables explained between 17 and $53 \%$ of corn yields (based on r-square values) in rotation in the subsequent season, but were less valuable in predicting continuous corn yields. A preseason moisture shortage from September to May may negatively affect the next seasons' corn yield in rotation systems due to below average water storage in the profile.

\section{Regression analyses}

Two regression models were developed to associate corn yields with weather factors. The models performed differently in the various cropping systems. The variables in the first model were Biological Window 2 (BW2) and May temperature (MAT). In model 2 explanatory variables were August temperature (AGT) and June-August SPI (AGSS). The second model accounted for a higher percentage of variability in corn yield in the continuous systems than model 1 (Table 6). In contrast, model 1 was more appropriate than model 2 in predicting fluctuations in soybean yields in continuous systems (Table 7). Both models explained more variation in soybean $\left(R^{2}=0.73,0.83\right)$ than in corn yields $\left(R^{2}=0.32,0.42\right)$.

High temperature at planting in May (MAT) was associated with increased corn yields in the 2-yr and 4-yr rotations
Table 6. Corn yield response to weather variables in eastern Nebraska.

\begin{tabular}{lclcccc}
\hline System $\neq$ & Model & Variable & $\begin{array}{c}\text { Reg. } \\
\text { Coeff. }\end{array}$ & $\begin{array}{c}\text { Std. } \\
\text { error }\end{array}$ & R-square & $\begin{array}{c}\text { Proba- } \\
\text { bility }\end{array}$ \\
\hline CC & 1 & BW2 & $0.29^{* *}$ & 0.08 & 0.32 & 0.0015 \\
& & May temp. & 2.28 & 1.53 & & \\
& 2 & August temp. & $-6.74^{* *}$ & 1.39 & 0.42 & 0.0001 \\
& & Jun-Aug SPI & 1.01 & 3.92 & & \\
S-C & 1 & BW 2 & $0.40^{* *}$ & 0.05 & 0.71 & 0.0001 \\
& & May temp. & $3^{* 15^{* *}}$ & 0.93 & & \\
& 2 & August temp. & $-6.77^{* *}$ & 1.08 & 0.61 & 0.0001 \\
& & Jun-Aug SPI & $7.63^{*}$ & 3.03 & & \\
O/CI-G-S-C & 1 & BW 2 & $0.35^{* *}$ & 0.06 & 0.60 & 0.0001 \\
& & May temp. & $1.89 \dagger$ & 1.01 & & \\
& 2 & August temp. & $-6.19^{* *}$ & 0.98 & 0.61 & 0.0001 \\
& & Jun-Aug SPI & $7.05^{*}$ & 2.77 & & \\
S-G-O/Cl-C & 1 & BW 2 & $0.56^{* *}$ & 0.05 & 0.80 & 0.0001 \\
& & May temp. & $2.43^{* *}$ & 0.94 &. & \\
& 2 & August temp. & $-9.59^{* *}$ & 0.98 & 0.78 & 0.0001 \\
& & Jun-Aug SPI & $9.07^{* *}$ & 2.77 & & \\
\hline
\end{tabular}

$\dagger, *, * *$ denote significance at $0.10,0.05$, and 0.01 probability levels respectively. $\ddagger \mathrm{CC}=$ continuous corn, $\mathrm{S}=$ soybean, $\mathrm{G}=$ sorghum, $\mathrm{O} / \mathrm{Cl}=$ oat + clover.

Table 7. Soybean yield response to weather variables in eastern Nebraska.

\begin{tabular}{|c|c|c|c|c|c|c|}
\hline System & Model & Variable & $\begin{array}{l}\text { Reg. } \\
\text { Coeff. }\end{array}$ & $\begin{array}{l}\text { Std. } \\
\text { error }\end{array}$ & R-square & $\begin{array}{l}\text { Proba- } \\
\text { bility }\end{array}$ \\
\hline \multirow[t]{2}{*}{$\mathrm{CS}$} & 1 & $\begin{array}{l}\text { BW2 } \\
\text { May temp. }\end{array}$ & $\begin{array}{l}0.13^{* *} \\
0.44^{*}\end{array}$ & $\begin{array}{l}0.01 \\
0.20\end{array}$ & 0.83 & 0.0001 \\
\hline & 2 & $\begin{array}{l}\text { Aug temp. } \\
\text { Jun-Aug SPI }\end{array}$ & $\begin{array}{r}-1.69^{* *} \\
3.79^{* *}\end{array}$ & $\begin{array}{l}0.24 \\
0.69\end{array}$ & 0.73 & 0.0001 \\
\hline \multirow[t]{2}{*}{ C-S } & 1 & $\begin{array}{l}\text { BW2 } \\
\text { May temp. }\end{array}$ & $\begin{array}{l}0.13^{* *} \\
0.21\end{array}$ & $\begin{array}{l}0.02 \\
0.29\end{array}$ & 0.69 & 0.0001 \\
\hline & 2 & $\begin{array}{l}\text { Aug temp. } \\
\text { Jun-Aug SPI }\end{array}$ & $\begin{array}{r}-1.59^{* *} \\
3.80^{* *}\end{array}$ & $\begin{array}{l}0.33 \\
0.92\end{array}$ & 0.59 & 0.0001 \\
\hline \multirow[t]{2}{*}{ G-S } & 1 & $\begin{array}{l}\text { BW2 } \\
\text { May temp. }\end{array}$ & $\begin{array}{l}0.11^{* *} \\
0.60^{*}\end{array}$ & $\begin{array}{l}0.02 \\
0.28\end{array}$ & 0.67 & 0.0001 \\
\hline & 2 & $\begin{array}{l}\text { Aug temp. } \\
\text { Jun-Aug SPI }\end{array}$ & $\begin{array}{r}-1.26^{* *} \\
3.86^{* *}\end{array}$ & $\begin{array}{l}0.33 \\
0.94\end{array}$ & 0.52 & 0.0001 \\
\hline \multirow[t]{2}{*}{$\mathrm{C}-\mathrm{O} / \mathrm{Cl}-\mathrm{G}-\mathrm{S}$} & 1 & $\begin{array}{l}\text { BW2 } \\
\text { May temp. }\end{array}$ & $\begin{array}{l}0.11^{* *} \\
0.77^{*}\end{array}$ & $\begin{array}{l}0.02 \\
0.33\end{array}$ & 0.57 & 0.0001 \\
\hline & 2 & $\begin{array}{l}\text { Aug temp. } \\
\text { Jun-Aug SPI }\end{array}$ & $\begin{array}{r}-1.21^{* *} \\
3.22^{* *}\end{array}$ & $\begin{array}{l}0.40 \\
1.12\end{array}$ & 0.38 & 0.0004 \\
\hline \multirow[t]{2}{*}{ G-O/Cl-C-S } & 1 & $\begin{array}{l}\text { BW2 } \\
\text { May temp. }\end{array}$ & $\begin{array}{l}0.12^{* *} \\
0.45\end{array}$ & $\begin{array}{l}0.02 \\
0.34\end{array}$ & 0.60 & 0.0001 \\
\hline & 2 & $\begin{array}{l}\text { Aug temp. } \\
\text { Jun-Aug SPI }\end{array}$ & $\begin{array}{r}-1.09 * * \\
4.34 * *\end{array}$ & $\begin{array}{l}0.39 \\
1.10\end{array}$ & 0.45 & 0.0001 \\
\hline
\end{tabular}

*,** denote significance at 0.05 and 0.01 probability levels respectively. $\mp C S=$ continuous soybean, $\mathrm{S}=$ soybean, $\mathrm{G}=$ sorghum, $\mathrm{O} / \mathrm{Cl}=$ oat + clover.

systems but not in continuous monoculture (Table 6). High temperatures at planting may stimulate soil biological processes such as breakdown of crop residues, seedling emergence, and enhanced root activity to better exploit soil nutrients. High August temperature in model 2 was detrimental to corn and soybean yields in all the systems as indicated by the negative regression coefficients (Tables 6 and 7). Among the variables tested in the two models, August temperature appeared to have the most deleterious effect on corn (regression coefficient $=-6.19$ to $-9.59, P=0.0001$ ). Stooksbury and Michaels (1994) and Teigen and Thomas (1995) associated reduction in corn yields with high temperatures in August; this is the period of the end of corn pollination and the time of maximum grain fill in Nebraska. Dirks and Bolton (1981) reported an insignificant response by corn to changes in climatic factors under low management and fertility levels; in our study the low cereal yields 
Table 8. Multiple regression models associating sorghum yields with key weather variables in individual cropping and fertilization systems.

\begin{tabular}{|c|c|c|c|c|c|c|}
\hline System¥ & Variable & $\begin{array}{l}\text { Regression } \\
\text { coeff }\end{array}$ & $\begin{array}{l}\text { Std. } \\
\text { error }\end{array}$ & Elasticity & $\begin{array}{c}\text { R- } \\
\text { square }\end{array}$ & $\begin{array}{l}\text { Proba- } \\
\text { bility }\end{array}$ \\
\hline CG-0 & $\begin{array}{l}\text { April temp. } \\
\text { May rain. }\end{array}$ & $\begin{array}{l}3.03 \\
0.36\end{array}$ & $\begin{array}{l}2.17 \\
2.74\end{array}$ & $\begin{array}{l}\text { NS } \\
\text { NS }\end{array}$ & 0.17 & 0.4 \\
\hline CG-80 & $\begin{array}{l}\text { April temp. } \\
\text { May rain. }\end{array}$ & $\begin{array}{c}5.78^{*} \\
-3.00\end{array}$ & $\begin{array}{l}2.43 \\
3.07\end{array}$ & $\begin{array}{l}3.7 \\
\text { NS }\end{array}$ & 0.47 & 0.06 \\
\hline CG-160 & $\begin{array}{l}\text { April temp } \\
\text { May rain }\end{array}$ & $\begin{array}{l}5.77^{* *} \\
-3.05\end{array}$ & $\begin{array}{l}1.98 \\
2.50\end{array}$ & $\begin{array}{l}3.3 \\
\text { NS }\end{array}$ & 0.57 & 0.02 \\
\hline S-G-0 & $\begin{array}{l}\text { April temp. } \\
\text { May rain. }\end{array}$ & $\begin{array}{c}4.39^{*} \\
-2.43\end{array}$ & $\begin{array}{l}1.69 \\
2.13\end{array}$ & $\begin{array}{c}2.95 \\
\text { NS }\end{array}$ & 0.52 & 0.04 \\
\hline S-G-80 & $\begin{array}{l}\text { April temp. } \\
\text { May rain. }\end{array}$ & $\begin{array}{l}5.60^{* *} \\
-2.08\end{array}$ & $\begin{array}{l}1.73 \\
2.19\end{array}$ & $\begin{array}{l}3.14 \\
\text { NS }\end{array}$ & 0.58 & 0.02 \\
\hline S-G-160 & $\begin{array}{l}\text { April temp. } \\
\text { May rain- }\end{array}$ & $\begin{array}{r}2.84 \dagger \\
-3.27 \dagger\end{array}$ & $\begin{array}{l}1.57 \\
1.98\end{array}$ & $\begin{array}{l}1.62 \\
0.15\end{array}$ & 0.46 & 0.06 \\
\hline S-C-Cl-G-0 & $\begin{array}{l}\text { April temp. } \\
\text { May rain. }\end{array}$ & $\begin{array}{r}3.61 \\
-2.82\end{array}$ & $\begin{array}{l}2.45 \\
3.09\end{array}$ & $\begin{array}{l}\text { NS } \\
\text { NS }\end{array}$ & 0.30 & 0.21 \\
\hline S-C-Cl-G-80 & $\begin{array}{l}\text { April temp. } \\
\text { May rain. }\end{array}$ & $\begin{array}{r}3.23 \\
-1.69\end{array}$ & $\begin{array}{l}2.51 \\
3.17\end{array}$ & $\begin{array}{l}\text { NS } \\
\text { NS }\end{array}$ & 0.20 & 0.35 \\
\hline S-C-Cl-G-160 & $\begin{array}{l}\text { April temp. } \\
\text { May rain. }\end{array}$ & $\begin{array}{r}2.58 \\
-0.10\end{array}$ & $\begin{array}{l}2.84 \\
3.59\end{array}$ & $\begin{array}{l}\text { NS } \\
\text { NS }\end{array}$ & 0.10 & 0.65 \\
\hline Cl-C-S-G-0 & $\begin{array}{l}\text { April temp. } \\
\text { May rain. }\end{array}$ & $\begin{array}{l}4.76^{*} \\
-2.92\end{array}$ & $\begin{array}{l}1.66 \\
2.09\end{array}$ & $\begin{array}{c}3.16 \\
\text { NS }\end{array}$ & 0.57 & 0.02 \\
\hline Cl-C-S-G-80 & $\begin{array}{l}\text { April temp. } \\
\text { May rain. }\end{array}$ & $\begin{array}{r}3.14 \\
-3.52\end{array}$ & $\begin{array}{l}1.99 \\
2.51\end{array}$ & $\begin{array}{l}\text { NS } \\
\text { NS }\end{array}$ & 0.38 & 0.11 \\
\hline Cl-C-S-G-160 & $\begin{array}{l}\text { April temp. } \\
\text { May rain }\end{array}$ & $\begin{array}{c}3.54 \dagger \\
-3.19\end{array}$ & $\begin{array}{l}1.87 \\
2.37\end{array}$ & $\begin{array}{c}1.99 \\
\text { NS }\end{array}$ & 0.42 & 0.08 \\
\hline
\end{tabular}

$\dagger, * *$ denote significance at $0.10,0.05$, and 0.01 probability levels respectively.

‡ C=corn, $\mathbf{G}=$ sorghum, $\mathrm{S}=$ soybean, $\mathrm{Cl}=$ clover

with zero $\mathrm{N}$ in continuous cropping could explain the low $\mathrm{R}$ square values in corn (Tables 6) and in sorghum (Table 8).

Model 1 explained more variability in soybean yields than model 2 across all systems (Table 7). Predictive power of the models was lowest in the 4-yr rotational systems and lower in 2-yr rotation than in continuous sorghum, as evidenced by R-square values. The damaging effect of August temperature (AGT) was seen all soybean systems (Table 7). The June-August SPI for August was beneficial to soybean yields in all the systems, and significant in four of five of them (Table 7).

As previously described, sorghum has been reported as less sensitive to weather variability than com and soybean (Table 4). However, preplant temperature in April (APT) was positively related to sorghum yield in the fertilized monoculture and several rotation systems (Table 8). April temperature and May rainfall accounted for between 10 and $58 \%$ (based on R-square values) of the variability in sorghum yields in the individual cropping and $\mathrm{N}$-level combinations. Factors such as diseases, pests, and weeds were not considered in our study and may explain additional variability in sorghum yields. The elasticities in Table 8 show that seven out of 12 sorghum systems had higher yields due to higher April temperature. The present findings corroborate results of others (Peterson et al., 1990) that emphasize the resilience of sorghum to changing climatic conditions. Thus, sorghum may be an appropriate crop to grow under circumstances where past climatic information helps us measure a negative preseason SPI, but favorable April temperature. Elasticities for corn and soybean were less significant, and thus were not reported.

\section{CONCLUSIONS}

Results of this study demonstrate the potential of both 2yr and 4-yr crop rotations in enhancing crop yields in eastern Nebraska. Overall, corn and soybean yields were more sensitive than sorghum yields to variable weather patterns, thus making sorghum a more suitable crop to grow where we have limited preseason rainfall and favorable April temperatures. The first increment of $\mathrm{N}$ fertilizer ( $80 \mathrm{lb} \mathrm{N} / \mathrm{acre})$ greatly increased yield in corn and sorghum. In general, higher $\mathrm{N}$ fertilization (160 lb N/acre) increased yields to higher levels in monoculture systems but not in rotations. There were no significant differences in component crop yield variability (reported as economic risk) among systems or $\mathrm{N}$ levels. The use of composite weather variables (BW and SPI) derived from simple computer programs and climatic data to evaluate long-term yield variability in rotations was also illustrated. Two empirical models developed with BW and August temperature as key predictor variables explained between 32 and $80 \%$ of the yield variability in corn cropping systems and between 38 and $83 \%$ in soybean cropping systems. Values were lower for grain sorghum.

The most valuable information for management decisions is the crop reaction to preseason soil moisture (represented by SPI) and the response to applied $\mathrm{N}$ fertilizer. These data allow manipulation of the crop environment (e.g., maximize moisture availability by minimum tillage) and allocation of resources from inputs (e.g., purchase and apply moderate amounts of $\mathrm{N}$ fertilizer). The $\mathrm{BW}$ and growing season SPI values are useful in predicting the longer term potential performance of these crops in a given location, and in planning an optimum rotation sequence. In combination, these indices and weather variables could be used to decide to break rotation sequence in response to extremely favorable or adverse weather conditions just as one would respond to changes in relative prices for the different commodities in the marketplace. The analyses contribute to our understanding of how continuous cropping contrasts with rotation systems, and how both respond to variations in weather.

\section{REFERENCES}

Asghari, M., and R.G. Hanson. 1984. Nitrogen, climate, and previous effect on corn yield and grain N. Agron J. 76:536-542.

Crookston, R.K 1984. The rotation effect: What causes it to boost yield. Crops Soils 36(6):12-14.

Delcourt, G., and G.C. van Kooten. 1995. How resilient is grain production to climatic change? Sustainable agriculture in a dryland cropping region of western Can. J. Sust. Agric. 5:37- 57.

Dirks, V.A., and E.F. Bolton. 1981. Climatic factors contributing to year-toyear variation in grain yield of corn on Brookston clay. Can. J. Plant Sci. 61:293-305.

Doggett, H. 1970. Sorghum. Longmans Publishers, London. p.187.

Draper, N.R., and H. Smith. 1966. Applied regression analysis. John Wiley and Sons, New York.

Franzleubbers, A.J., C.A. Francis, and D.T. Walters. 1994. Nitrogen fertilizer response potential of corn and sorghum in continuous and rotated crop sequences. J. Prod. Agric. 7:277-284.

Fribourg, H.A., and W.V. Bartholomew. 1956. Availability of nitrogen from crop residues during the first and second seasons after application. Soil Sci. Soc. Am. J. 20:505-508.

Helmers, G.A., M.R. Langemeier, and J. Atwood. 1986. An economic analysis of alternative cropping systems for east-central Nebraska. Am. J. Altern. Agric. 1:153-158. 
Hendrix, J.W., K.J. Jones, and W.C. Mesmith. 1992. Control of pathogenic mycorrhizal fungi in maintenance of soil productivity by crop rotation. J. Prod. Agric. 5:383-386.

Hesterman, O.B., M.P. Russelle, C.C. Sheaffer, and G.H. Heichel. 1987. Nitrogen utilization from fertilizer and legume residues in legume-corn rotations. Agron. J. 79:726-731.

Jordan, N., D.D. Mortensen., D.M. Prenzlow, and K.C. Cox. 1995. Simulation analysis of crop rotation effects on weed seedbanks. Am. J. Bot. 82:390-398.

Koenning, S.R., D.P. Schmitt., K.R. Baker, and M.L. Gumpertz. 1995. Impact of crop rotation and tillage system on Heterodera glycines population density and soybean yield. Plant Dis. 79:282-286.

Liebman, M., and T. Ohno. 1997. Crop rotation and legume effects on weed emergence and growth: Applications for weed management. p. 181-221. In J.L. Hatfield et al. (ed.) Integrated weed and soil management. Ann Arbor Press, Chelsea, MI.

McKee, T.B., N.J. Doesken, and J. Kleist. 1992. The relationship of drought frequency and duration to time scales. p. 179-184. In Proc. 8th Conf. on Applied Climatology, Anaheim, CA. 17-22 Jan. Am. Meteorological Soc., Boston.

McSorley, R., D.W. Dickson, J.A. de Brito, T.E. Hewlett, and J.J. Frederick. 1994. Effects of tropical rotation crops on Meloidogyne arenaria population densities and vegetable yields in micro plots. J. Nematol. 26:175-181.

Nester, J., and W. Wasserman. 1974. Applied linear statistical models. Richard D. Irwin, Inc., Homewood, IL.

Passioura, J.B. 1973. Sense and nonsense of crop simulation. J. Aust. Inst.. Agr. Sci. 39:181-183.

Peterson, T.A., C.A. Shapiro, and A.D. Flowerday. 1990. Rainfall and previous crop effects on crop yields. Am. J. Altem. Agric. 5:33-37.

Peterson, T.A., and G.E. Varvel. 1989a. Crop yield as affected by rotation and $N$ rate: I. Soybean. Agron. J. 81:727-731.

Peterson, T.A., and G.E. Varvel. $1989 \mathrm{~b}$. Crop yield as affected by rotation and N rate: II. Grain Sorghum. Agron. J. 81:731-734.
Peterson, T.A., and G.E. Varvel. 1989c. Crop yield as affected by rotation and N rate: III. Com. Agron. J. 81:735-738.

Peterson, W.R., D.T. Walters, R.J. Suppala, and R.A. Olson. 1991. Yield and economic aspects of irrigated cropping systems in eastem Nebraska. J. Prod. Agric. 4:353-360.

Stockle, C.O., S.A. Martin, G.S. Campbell. 1994. CropSyst, a cropping systems simulation model: Water/nitrogen and crop yield. Agric. Syst. 46:335-359.

Stooksbury, D.E., and P.J. Michaels. 1994. Climate change and large-area corn yield in the southern United States. Agron. J. 86:564-569.

Tabachnick, B.G., and L.S. Fidell. 1983. Using multivariate statistics. Harper and Row, New York.

Teigen, L.D., and M. Thomas, Jr. 1995. Weather and yield, 1950-94: Relationships, distributions, and data. USDA-ERS Commercial Agric. Div. Staff Paper no. 9527.

Thompson, L.M. 1962. Evaluation of weather factors in the production of wheat. J. Soil Water Conserv. 17:149-156.

Van Wambeke, A. 1987. Soil moisture and temperature regimes of central America, Caribbean, and Mexico. Cornell Univ. Dep. of Agronomy Soil Manage. Supp. Serv. Tech. Monogr. no. 16.

Van Wambeke A., P. Hastings., and M. Tolomeo. 1992. Newhall simulation model-A BASIC program for the IBM PC (DOS 2.0 or later). Comell Univ. Dep. of Agronomy, Ithaca, NY.

Varvel, G.E. 1994. Rotation and nitrogen fertilization effects on changes in soil carbon and nitrogen. Agron. J. 86:319-325.

Wall, J.S., and W.M. Ross. 1970. Sorghum production and utilization. AVI Publishing, Westport, CT. p. 167.

Waltman, W.J., E.J. Ciolkosz., M.J. Mausbach., M.D. Svoboda., D.A. Miller, and P.J. Kolb. 1997. Soil climate regimes of Pennsylvania. Pennsylvania State Univ. Agric. Exp. Station Bull. no. 873.

Williams, G.D.V., M.I. Joynt, and P.A. McCormick. 1975. Regression analysis of Canadian prairie crop-district cereal yields, 1961-1972, in relation to weather, soil and trend. Can. J. Soil Sci. 55:43-53. 